\title{
Artistic
}

\section{THE MOTION COMIC JAKA BEREK}

\author{
Sutikno $^{1}$ and Eko Supriyanto ${ }^{2}$ \\ ${ }^{1}$ Indonesian Institute of the Arts Surakarta, Indonesia \\ ${ }^{2}$ Indonesian Institute of the Arts Surakarta, Indonesia \\ E-mail correspondence: yasinconan@gmail.com
}

\begin{abstract}
In the past, people watched a theater called Ludruk on the mobile stage and on television. However, currently Ludruk's art is almost out of date. From this phenomenon, the researchers formulated the problem, namely how the local story artworks of Sawonggaling content can be transformed into a motion comic animated film using a three-act structure. The method of making comic motion animation for the legend of Jaka Berek uses two approaches, namely the method of making animation and the method of making comics. Both of them are done in 3 stages, namely pre-production, production and post-production. The results of the making of this motion comic animation show that the effort to bring back the legendary story that has long been drowned requires some appropriate medias that is easily understood by the current generation. The making of motion comics originating from legendary stories must be based on research and literature studies in order to give the spirit to the artwork that will be produced.
\end{abstract}

Keywords: Motion comics, animated films, and Jaka Berek

\begin{abstract}
ABSTRAK
Dahulu orang menonton teater bernama Ludruk di panggung keliling dan televisi. Namun, saat ini kesenian Ludruk itu sudah nyaris punah ketinggalan zaman. Dari fenomena tersebut, maka peneliti merumuskan permasalahan yaitu bagaimana karya cerita lokal konten Sawonggaling dapat diwujudkan menjadi film animasi komik gerak dengan menggunakan struktur tiga babak. Metode pembuatan animasi komik gerak legenda Jaka Berek ini menggunakan dua pendekatan yaitu metode pembuatan animasi dan metode pembuatan komik. Keduanya dikerjakan dalam 3 tahapan yakni praproduksi, produksi, dan pascaproduksi. Hasil dari pembuatan animasi komik gerak ini menunjukkan bahwa upaya memunculkan kembali cerita legenda yang sudah lama tenggelam dibutuhkan beberapa media yang tepat dan mudah dipahami oleh generasi sekarang ini. Pembuatan komik gerak bersumber dari cerita legenda harus didasari dengan penelitian dan studi literature agar dapat memberi ruh pada karya seni yang dihasilkan.
\end{abstract}

Kata kunci: Komik gerak, film animasi, dan Jaka Berek

34 | ARTISTIC : International Journal of Creation and Innovation 


\section{Introduction}

Technology is created to simplify and increase human effectiveness. During the development of science, technology will also develop so that it affects behavior and mind-set that were traditional in nature with technological advances to sociocultural changes. According to Soekanto (1990), one of the biggest factors in sociocultural change is technology. Technology, like two sides of a coin, can have positive and negative effects. But, how can technology support cultural values.

Social change is also seen in performing arts. The audience enjoys the show using a smartphone. Beside being a recording device, a smartphone is also a means of self-storage for appearing on social media to want to be known by many people, connect with the outside world and spread information online on social media.

Social media, commonly called online media, has complex capabilities, because it contains text, buttons, documents, audio and visuals, making it more valuable than other media. Each of individu can act as a subject, consumer and respondent. The advantages offered by online media make the information feel interactive so that it has more capability to introduce cultural literacy. Online media can provide easy information and global culture to enter a country, so that making our worries will weaken the local culture. However, information media is also very effective in promoting local culture which is starting to fade. According to T. Flew, broadly information media can create opportunities for the re-emergence of a hidden society and culture (Flew, 2008).

Sawunggaling is a local folk legend from Surabaya. According to cultural observer, Yousri Nur Raja Agam MH, this story firstly appear in 1686. The story of Jaka Berek from 1960 - 1990 was widely adapted in the Ludruk performance. Almost all of Ludruk groups have performed it. Besides in Ludruk, Jaka Berek's story is also adapted into the comic. Over time, this local content has now lost its existence and is displaced by film shows on social media, because it is considered unattractive. From the existing phenomena, it is hoped that technology can encourage the emergence of local cultural values that were lost in the digital era, with a different perspective from the story of its predecessors. 


\section{Artistic}

The author makes the local story of the Sawonggaling content an animated motion comic film using a three-act structure. Based on the above background, the problem is formulated, namely how the local stories of Sawonggaling content can be developed into animated motion comic film using a three-act structure.

\section{Literature Review}

\subsection{Motion Comic}

Motion comics are included in the animated film family by combining animation film techniques, motion graphics and comics. Motion comics are a combination of multimedia elements such as images, text, sound, and the concept of a film (Eisner, 2005). Conventional comics consist of several interconnected picture panels in which there are word balloons, narrative text and action sound effects represented by text. Motion comics according to S. McCloud, are unlimited canvases that have a concept, storyline, style and comic elements presented in digital form using various media including image panels, dialogue sound, audio, effects and motion animations (McCloud, 2000).

The transition from panel to panel in conventional comics is still used in motion comics, including from time to time, action to action, subject to subject, and scene to scene. Apart from the panel to panel switching animation in motion comics, audio is the next important component. Sounds in motion comics are divided into several parts, including:

a) Word Balloon Audio: A voice in the form of a dialogue that is used by a character or subject in communicating.

b) Audio Narration: Voice in the form of dialogue that is used to tell the narrative story.

c) Audio Enviroment Ambient: Supporting voice amplifies the story through audio

d) Audio Instruments Background: Audio in the form of instrument sounds to add to the atmosphere in the form of music, natural sounds or animals.

Movement in conventional comics is depicted with lines as the manifestation of wind or wind lines. Whereas in motion comics, movements are carried out in the form of 
animated object movements or panel movements. Panels or static moving objects according to the desired pattern.

\subsection{The legend of Jaka Berek}

In 1960-1990, many legends were adapted in the Ludruk performance. Ludruk adapts many folk stories, especially the story of Jaka Berek, but is now displaced by foreign films, especially on social media content. Generation $\mathrm{Z}$ youths enjoy Korean dramas more than local content. The number of local stories is insufficient when compared to foreign content. Meanwhile, so far Indonesian comics and animations tend to refer to comics and animations from Japan and America (Sugihartono, Dharsono, \& Guntur, 2020). In addition, it is also not supported by the use of new technology.

On the basis of this phenomenon, the writer wants to make Jaka Berek's story into film media, especially motion comic animation. The story is transformed into a comic form, but is given animated motion on the main object and panels. Motion in the form of zooming, moving, panning and rotating. Text balloons still exist like comics in general, but they are also given dialogue in the form of a dialect of the Suroboyoan Javanese Ludruk theater. To add to the atmosphere given background music and supporting voices.

\subsection{Three-Acts Structure}

The structure of the story is very important in filmmaking, as the body of the story structure is the backbone of the film. In order for the film's story to look dynamic and interesting, the storyline must be arranged so that the audience can last a long time watching the film.

Some of the story structures that are widely used in filmmaking, simple and effective, are the three-act story structure (Field, 1984). The film is divided into three story chapters, including: 1) Initial Round, about character introduction; 2) Middle Stage, where problems faced by the characters emerge; and 3) Final Act, where the characters solve problems. 


\section{Artistic}

\subsection{Digital Painting of Realism}

Film uses a camera for the shooting process, but it is different from motion comic film which uses an animated image as if it is moving or can be called a Motion Graphic. According to M. Khrisna, the Hybrid Animation method is that each panel is drawn manually on paper with a pencil according to the storyboard to give a pattern, then forwarded on the computer to process the drawing and coloring using digital board hardware called a graphics tablet (Khrisna, 2002).

Sindoesoedarsono Soedjojono is the father of modern Indonesian Realist Painting, which has the characteristic of rough-textured painting (Zuliati, 2014). The realist school describes someone or something as reality even though it is ugly in the public eye. Soedjojono painted mountains, hills and roads from different angles, trying to portray Indonesia's natural consciousness free from the general way according to oneself (Soedjojono, 2000).

Through the characteristics of Soedjojono's paintings, the composer adapts them to be applied to each picture panel. The brush strokes are adjusted using shape dynamics to make them look natural, controlling the brush size, angle and roundness. Transparent brush is to adjust the pressure of the brush, sometimes in painting we need thick and thin brush strokes according to the pen pressure on the digital tablet board. Long and free imaginary lines form the field of dynamic objects. The combination of stroke pressure and brush options creates a realist painting style.

\subsection{Art Work Review}

Watchmen is a motion comic hero film made by Warner Bros. and DC Comic in 2005. The first and biggest comics maker company tells about heroes. The visuals of the Marvel hero motion comic films have a characteristic feature of accentuating firm, thick and sharp lines to build the characters of the hero characters. The nuance of comic graphics is still attached with several animated movements that are only performed by the main character or story-boosting object in each panel. Apart from the audio dialogue, there are also word balloons in each scene, thereby reinforcing 
the comic impression of the motion.

The author uses references in making this Jaka Berek animated comic film, including:

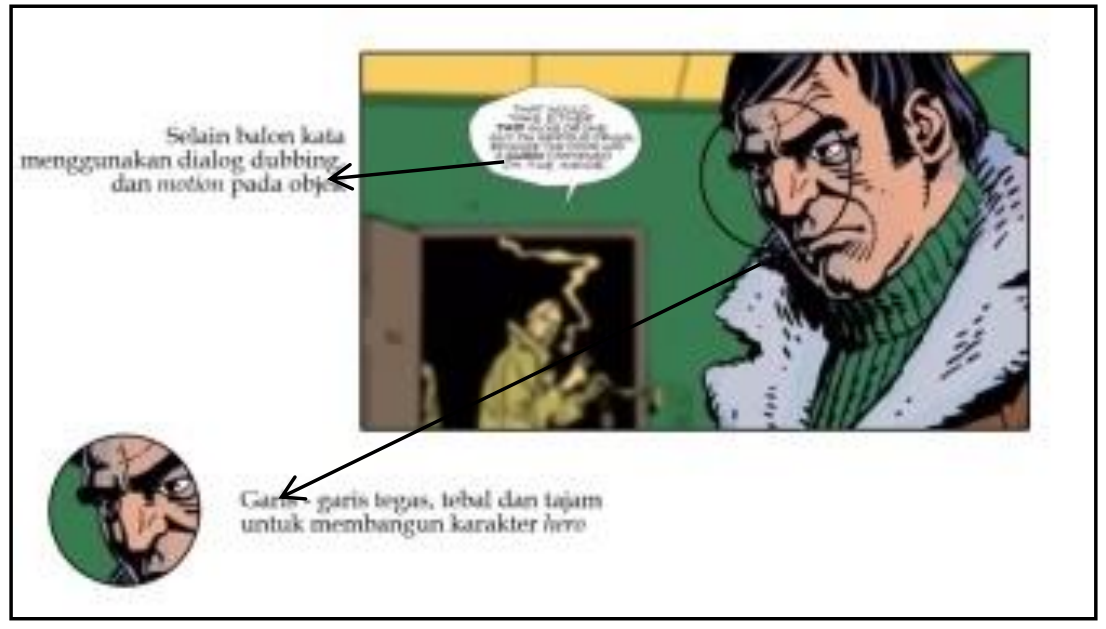

Figure 1. Characteristics of motion comics Watchmen

The motion comic film I am Legend was made in 2007 by Ian Kirby. Visual comics have a realist image flow using digital watercolor effects so that they build a more dramatic story character and eliminate the stiff impression of a previous motion comic, produced by Marvel. The audio dialogue continues to appear and is supported by comic-style speech bubbles.

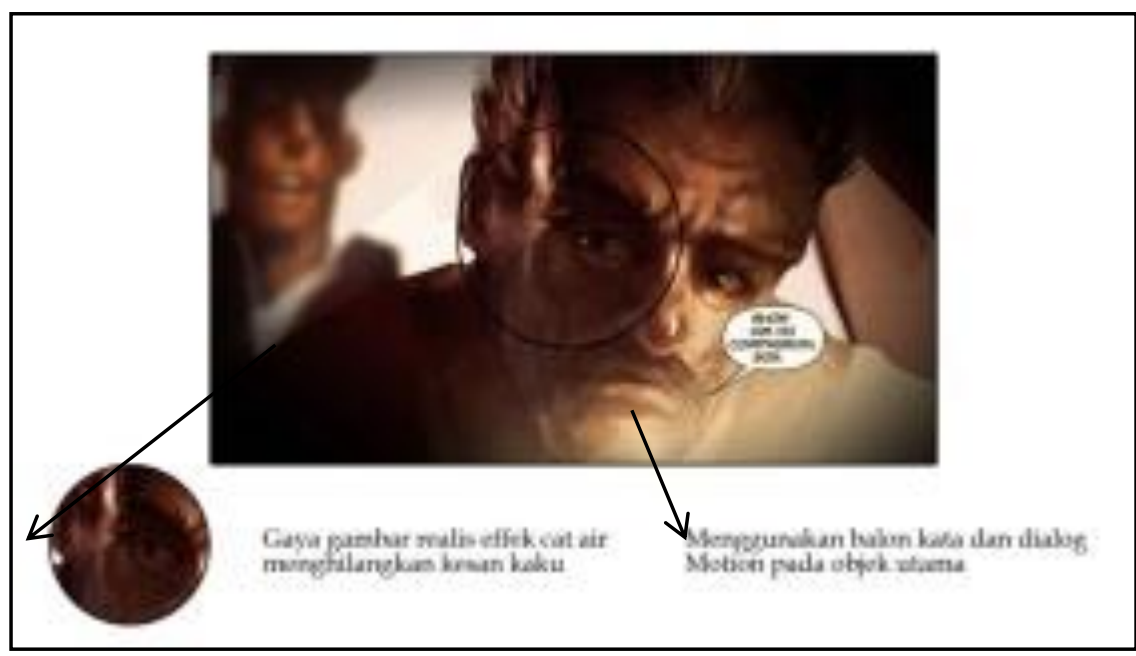

Figure 2. Characteristics of graphics in motion comic I am Legend 


\section{Artistic}

Several motion comic films raised legends, including the story of King Arthur, the legendary king of Great Britain, produced by Comflix Studios. This comic film has strong characteristics like the comics produced by Marvel. The motion comic film Dracula vs King Arture has a three-act film structure, a classic structure that is widely used in films.

Roda Pantura is Indonesia's first animated film to enter the 2017 Internationales Trickfilm Festival Stuttgart (ITFS) in Germany. Animator Hizkia Subiyantoro displays visual elements around him, especially the Pantura area (North Java coast) as self-identity in conveying messages. The local strength of the content shown in the film Roda Pantura.

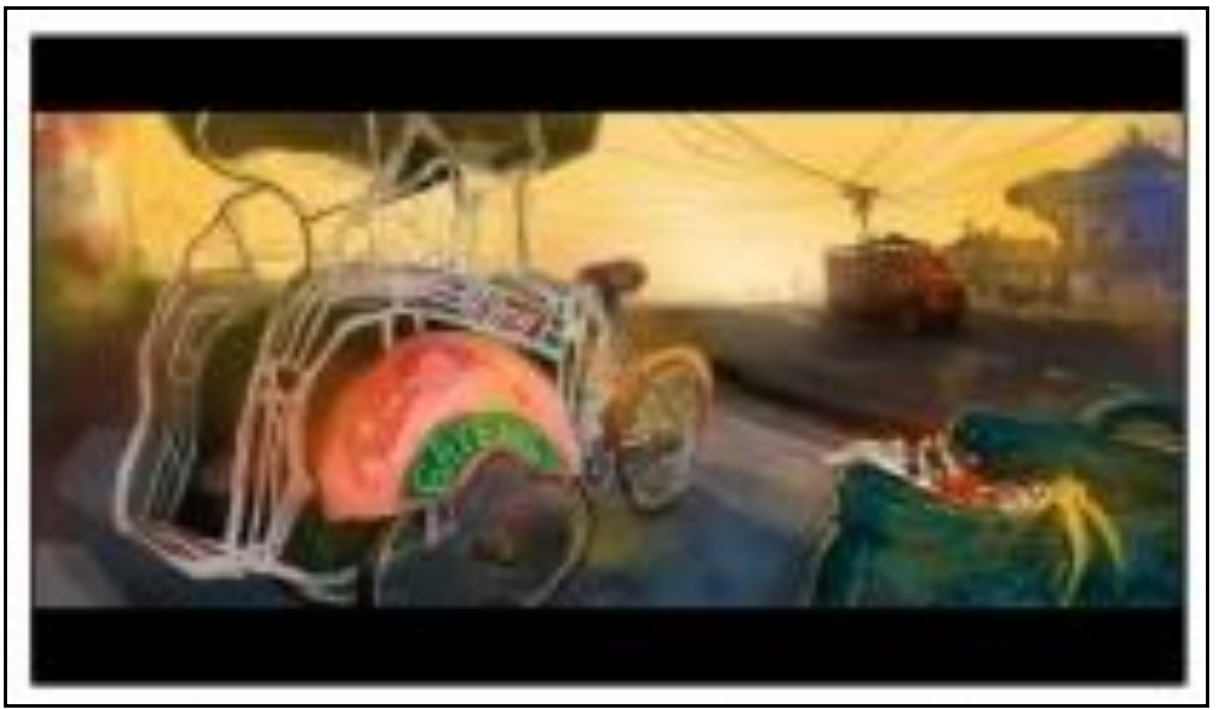

Figure 3. Realist graphic characteristics in animated films Roda Pantura

Rani Pramesti's Chinese Whispers film is a motion comic animated film about the May 1998 Riots. The drawing style is simple with black and white to highlight the monologue in this film.

Based on some of the references above, the writer wants to make an animated motion comic film with a puppeteer monologue and Ludruk style in the East Javanese language using realist visuals, digital painting techniques, monochrome colors, and using a three-act story line. 


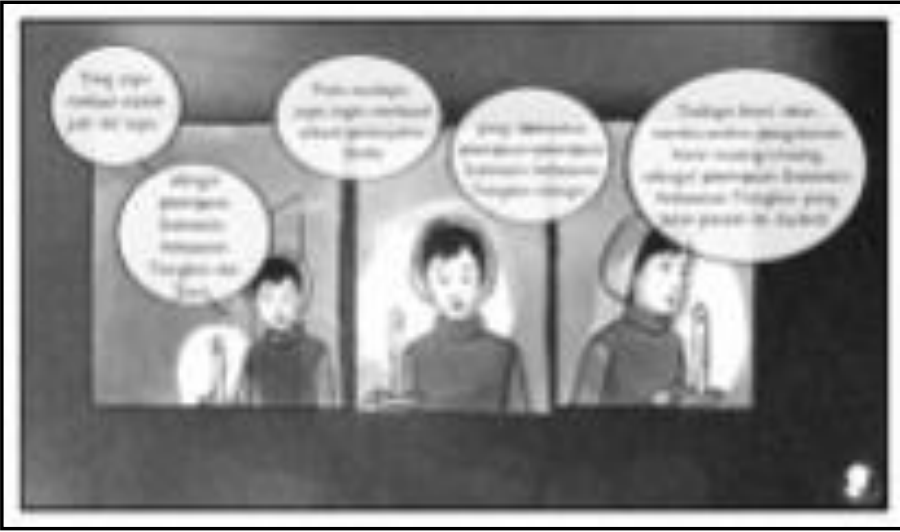

Figure 4. Realist graphic characteristics and black and white on film Chinese Whispers

\section{Creation Methodology}

The creation of this motion comic animation film uses Practice-Led Research. Research is a research strategy carried out through practice, mainly using certain methodologies and methods that are familiar to practitioners (Guntur \& Sugihartono, 2015). This study aims to produce a comic motion animation film of the legend of Jaka Berek. This method of making motion comics uses a combined two-model approach. The production model animates and builds comics from McCloud (1993) as illustrated in the chart below .

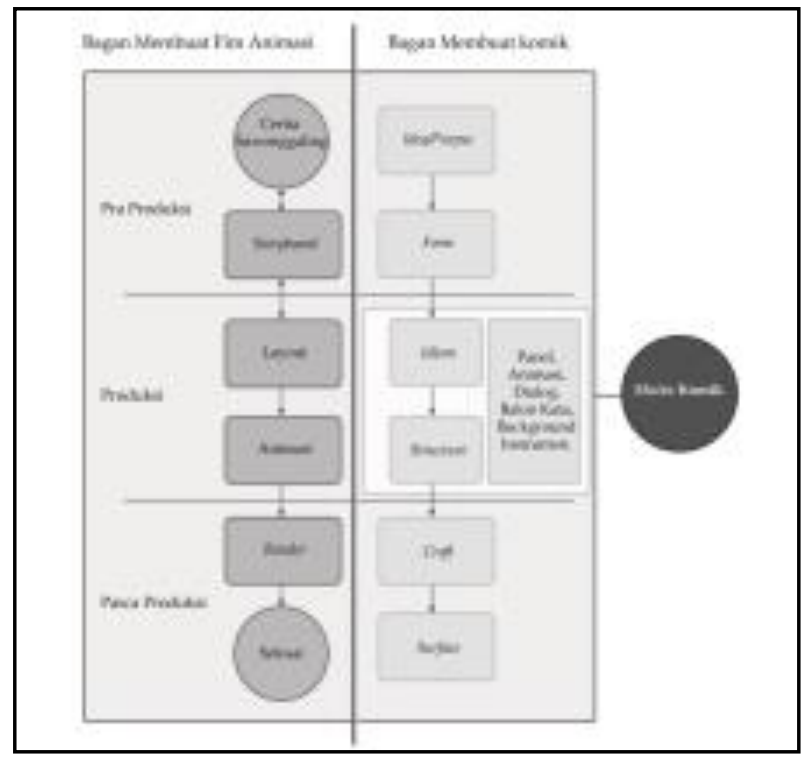

Chart 1. Motion comic creation chart (Adaptated : Sutikno, 2020) 


\section{Artistic}

\section{Discussion}

\subsection{Design Concept}

The making of Jaka Berek's animated comic motion films uses two approaches, namely the concept of stories and works of art.

\subsubsection{Story}

The author creates this animated comic film based on the results of an analysis of the regional approach, the time of occurrence and the natural environment in a spatial context, then connected with existing legends, so that this work does not detract from the original story but reinforces the legend. The target of this film is the young generation aged 7-20 years or so-called generation $\mathrm{Z}$. The author formulates the following story framework:

1). Tumenggung Jayengkrono never visited Lidah Donowati again until Dewi Sangkrah gave birth to a child. Dewi Sangkrah is the second wife of a relationship that Tumenggung Jayengkrono has kept secret, so that her whereabouts are unknown to the kadipaten (district) officials.

2). Jaka Berek grew and developed from a baby to crawling, which in turn liked chickens. Ki Karyo's house on the edge of the Kadipaten (District) of Surabaya and close to the forest, made Jaka Berek have no close friends. Jaka Berek's closest friends are livestock owned by Ki Karyosentono.

3). His love for chickens made Jaka Berek willing to do anything, including protecting his chickens from poisonous snake prey. The snake bite resulted in a battle of poison and blood. Jaka Berek in the legend is a "strong" and invincible person.

4). Jaka Berek's collision when he was a teenager experienced many things.

a. Jaka Berek's favorite cockfighting reached the surrounding villages. In its day, cockfighting was a tool for socializing between people.

b. Chicken Jaka Berek named Sawonggaling often wins and chooses to compete. The author assumes that the Sawonggaling chicken is a mixture of native (forest) chickens and native chickens. Sawonggaling is a brave and 
selective chicken with sharp claws and can jump and fly high.

c. Jaka Berek became a strong child and naturally trengginas because as a child he did things that were done by adults, such as looking for wood, water in the lake, playing the kettle, learning archery and martial arts.

5). Jaka Berek's battle with panthers looking for prey and finally won by Jaka Berek. Indonesia is very rich in the form of wilderness with large trees and various animals. There is a saying Jalmo Moro Jalmo Mati who dares to go into him will die so scary that expression. No one dares to touch the forest except for people who have high abilities in martial arts.

The storyline is translated into a three-act plot structure as follows:

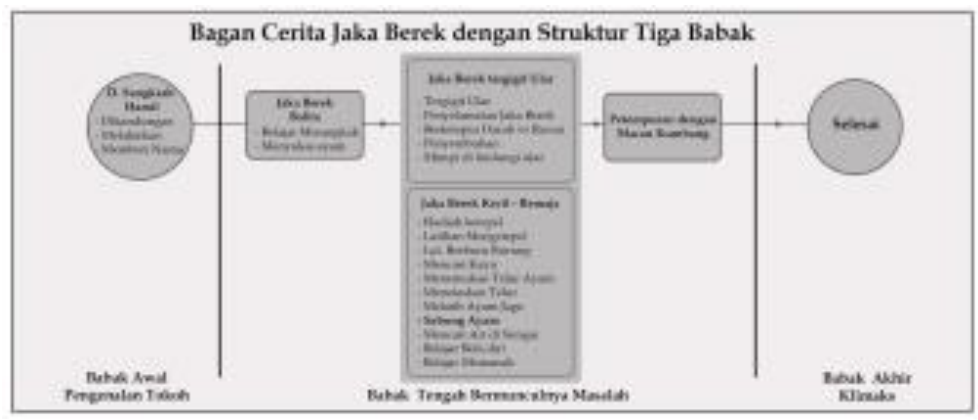

Chart 2. Jaka Berek's story chart (Design: Sutikno, 2020)

\subsubsection{Concep Art}

Concept art is a work of illustration as an initial form, reference or visual representation of design to conform to design goals (Suwasono, 2017). The making of motion comic animation requires concept art first as a reference for illustration of the characters, nature, panel shapes, properties, colors and text so as not to deviate from the desired illustration goal. Concept art in animation is the identification of all images of animated visual material as an artistic guide for animators (Shamsuddin, 2014).

Tillman (2011) argues that characters have a role in conveying story messages to audiences such as gender, age, role, anatomy and proportion. The following is the character design for each character in the Sawonggaling story: 


\section{Artistic}

\section{1). Jaka Berek}

The embodiment of Jaka Berek's consists of two views: First, the appearance when a toddler (5 years) uses cloth only as a cawet (underpants), and second, uses short pants tied by a cloth so that it doesn't fall down when used. The two visuals of Jaka Berek's character were without clothes because at that time clothes were only worn by aristocrats.

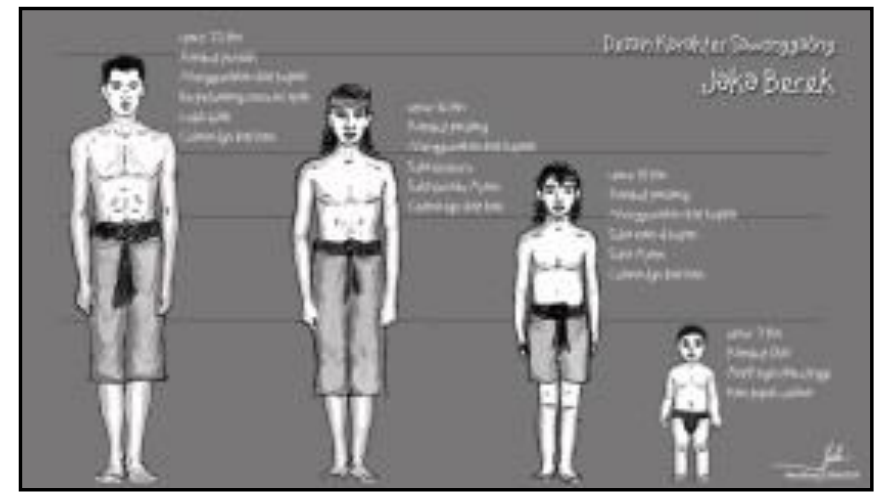

Figure 5. Character of Jaka Berek

(Design: Sutikno, 2020)

\section{2). Tumenggung Jayengkrono and Dewi Sangkrah}

Dewi Sangkrah wears a cloth wrapped around a shawl (the jarik cloth is used to wrap around the body). While the Tumenggung Jayengkrono character uses a wasrah (long cloth), dodot and a belt. Wasrah wrapped around the waist and then tied with a belt (Van Dijk, 2005). The jewelry used was necklaces, bracelets, shoulder bracelets and headbands.

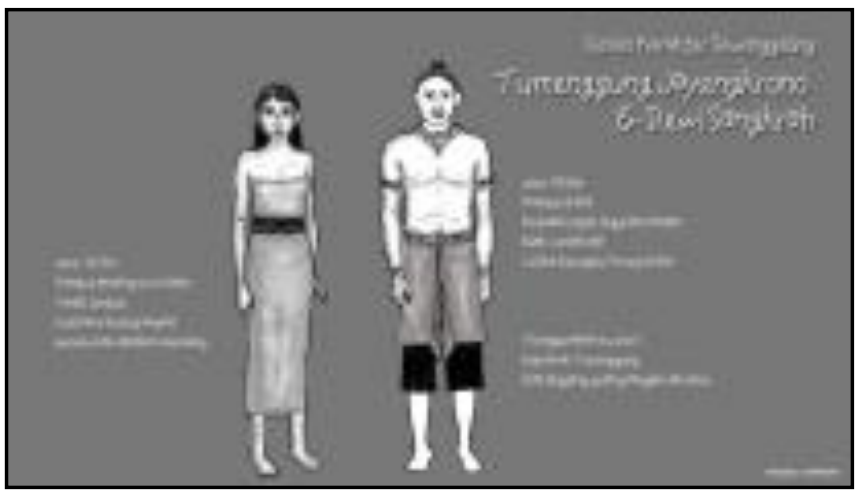

Figure 6. Character of Tumenggung Jayengkrono \& Dewi Sangkrah (Design: Sutikno, 2020) 


\section{3). Ki Karyosentono and Biyung Suruh}

The embodiment of Ki Kayo's character uses a 1/3 piece cloth tied with a cloth as a belt. Biyung Suruh uses a cloth wrapped around a small cloth as a belt like the one used by Dewi Sangkrah.

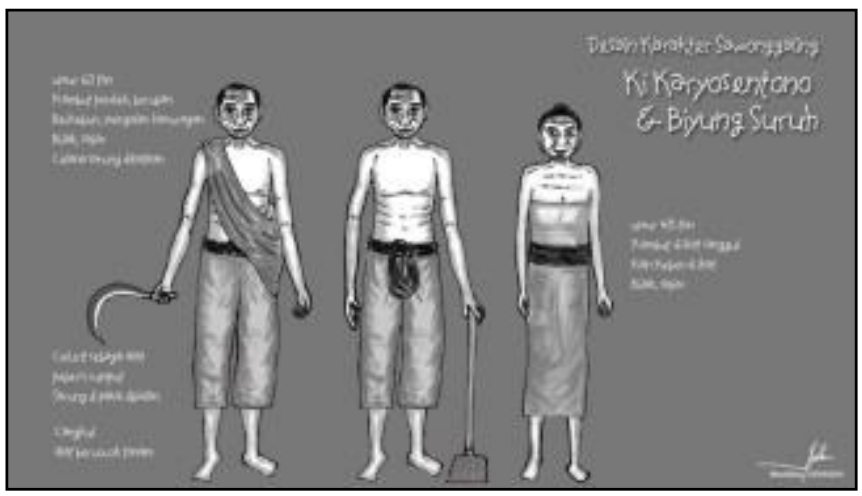

Figure 7. Character of Ki Karyosentono and Biyun Sangkrah (Design: Sutikno, 2020)

\section{4). Property}

The properties depicted in this animated comic film include houses, the environment in the form of plants and forests as well as animals around such as chickens, goats, deer and horses. The house design in the form of a limasan house is very popular in most Javanese homes (Dakung, 1981). With a pyramid-shaped roof structure using terracotta tiles or simple woven bamboo materials. The walls use wood.

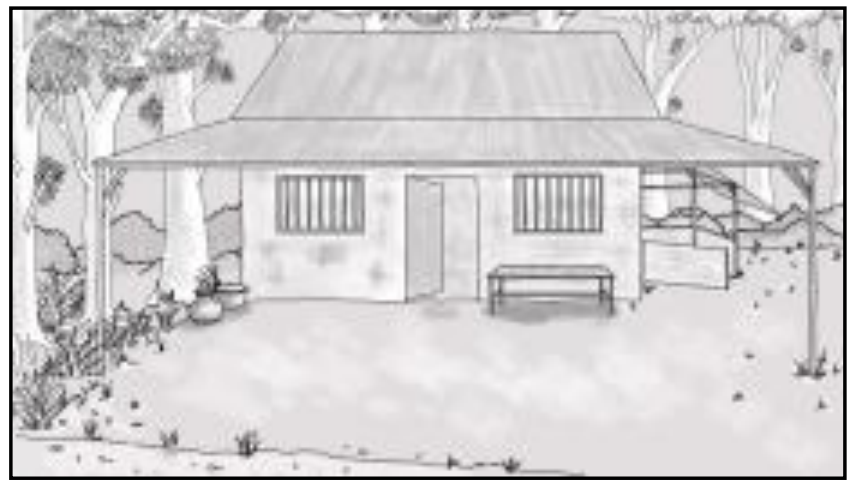

Figure 8. House of Biyung Suruh (Design: Sutikno, 2020) 


\section{Artistic}

5). Forests

At that time Lidah Donowati was a forest in the outskirts of Surabaya district, so there were many shrubs and rocks that were typical of the forests in Indonesia. Homogeneous tropical forest inhabited by many large trees and animals.

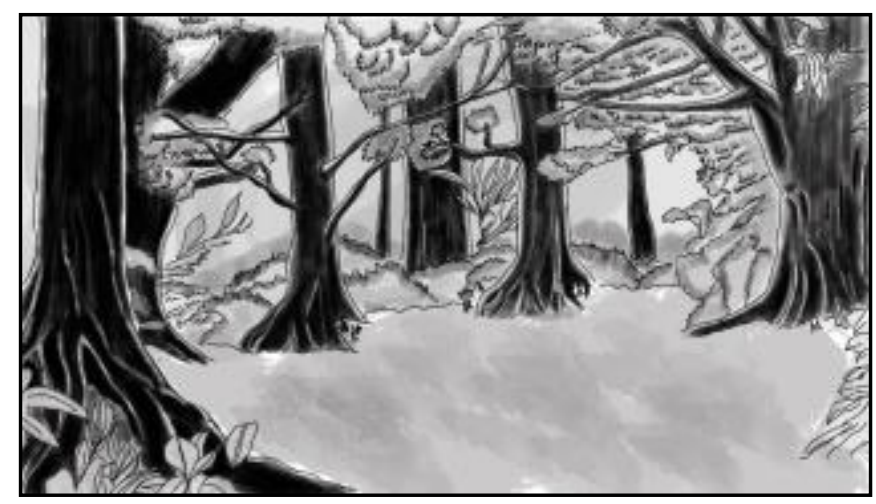

Figure 9. Visual forest

(Design: Sutikno, 2020)

6). Panels

Conventional comics rely on panels in the order of the story line. An interesting comic is if the order of the panels is neatly arranged it doesn't confuse the reader. Generally the order of the panels is clockwise from left to right. In comic motion, the use of panels is still cursed, because panels are the main element of comics.

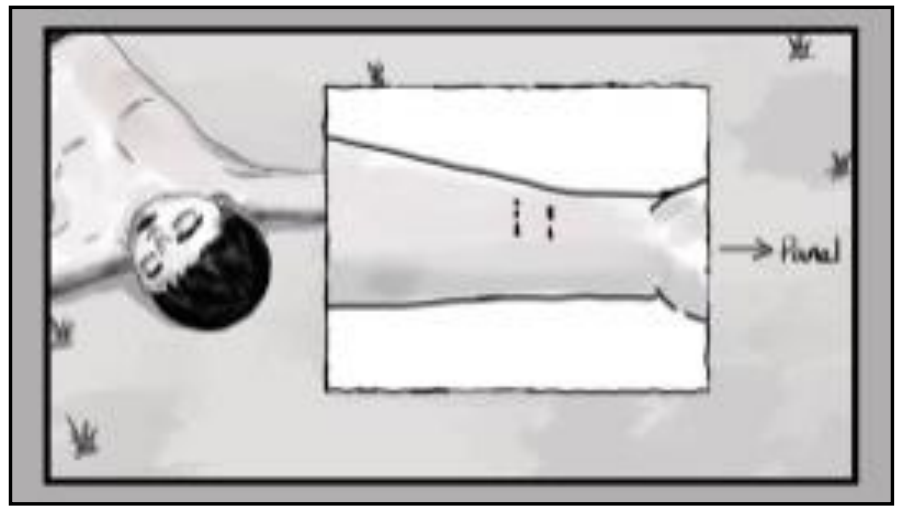

Figure 10. Panel as background and sub panel (Design: Sutikno, 2020) 


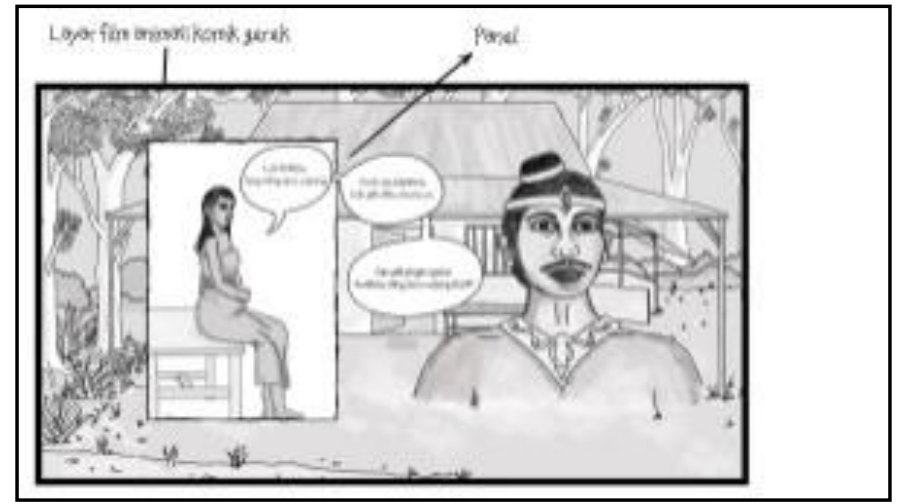

Figure 11. Animated background with panels and sub-panels (Design: Sutikno, 2020)

7). Word Balloons

The word balloon is a depiction of dialogue between characters in comics. The word balloon used consists of 3 visual images, including:

a). The dalang word balloon as the narrator is in the form of an elongated asymmetrical box surrounded by a black border. The font uses Al Musement at 45 pt.

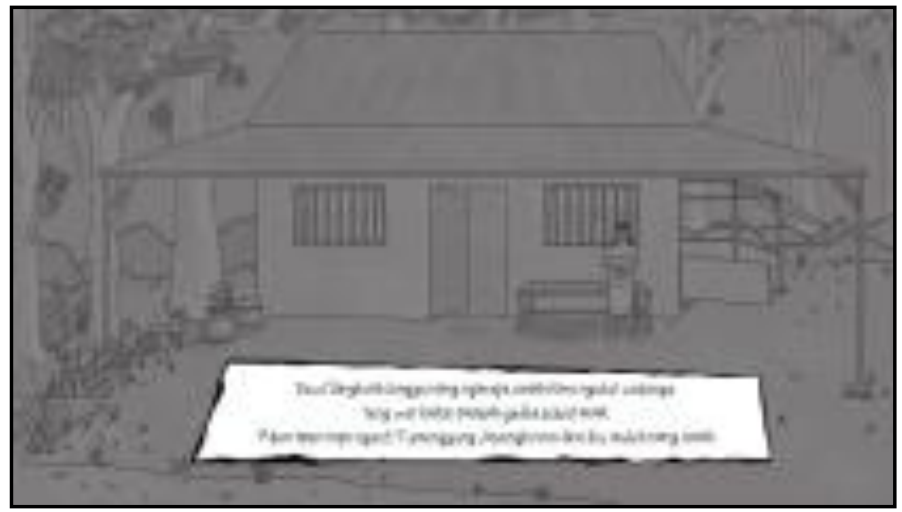

Figure 12. The narrator or dalang said balloon (Design: Sutikno, 2020)

b). The character dialogue word balloon uses an oval circle that is given a sharp line leading to the speaking character. The font uses Al Musement at $45 \mathrm{pt}$. 


\section{Artistic}

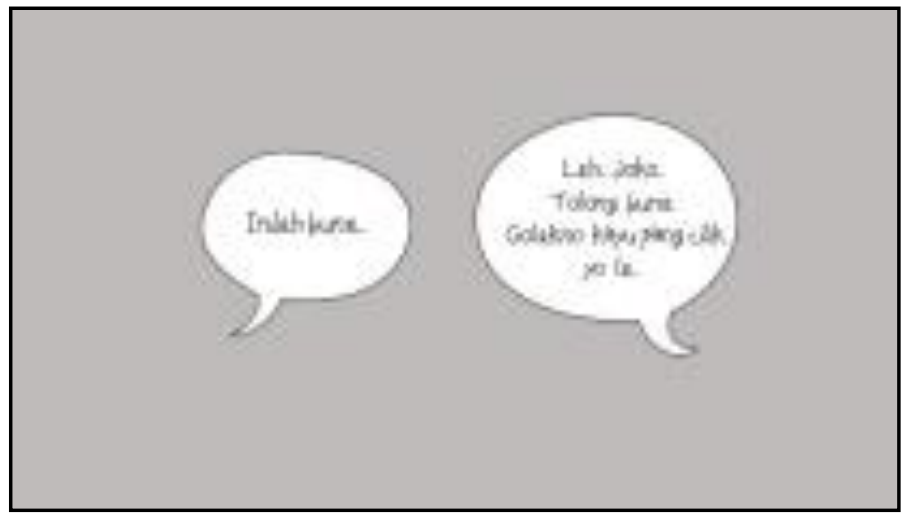

Figure 13. Word balloon dialogue character

(Design: Sutikno, 2020)

c). The thought and mumble word balloons use an oval circle that is given 3-4 pictures of a circle and gets smaller towards the speaker or character having a dialogue. The font uses Al Musement at 45 pt.

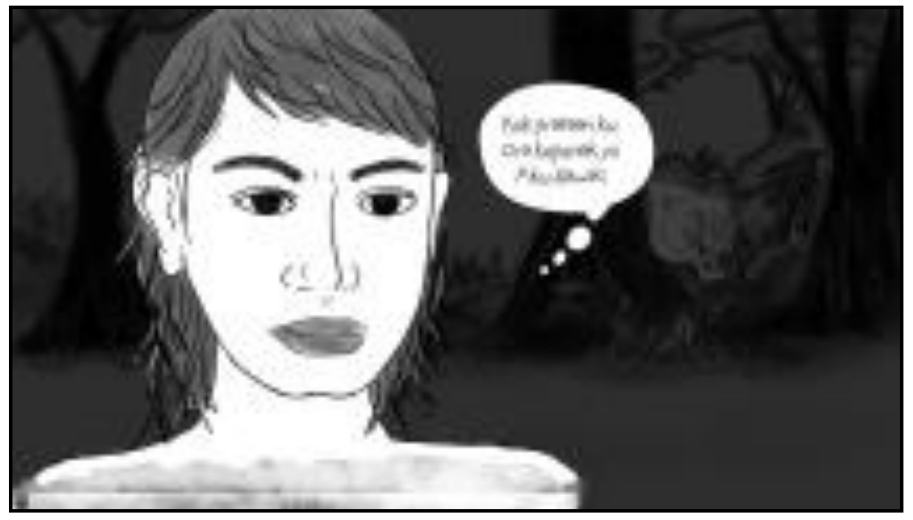

Figure 14. The speech balloon character thinks and mumbles (Design: Sutikno, 2020)

\subsection{Production Stages of Jaka Berek Film}

\subsubsection{Pre-production}

The pre-production stages of the making of Jaka Berek's animated comic motion films can be described in the concept of 5 main stories. This can be seen in the outline of the film based on a three-act structure.

1). Film Outline

The film outline is more detailed in the details of the story that has been 
arranged in a three-act story structure that is described in a scene. The outline of the film can be seen in the graph of the ups and downs of the story's mood, so that the film can be controlled according to the production design so that it is not monotonous.

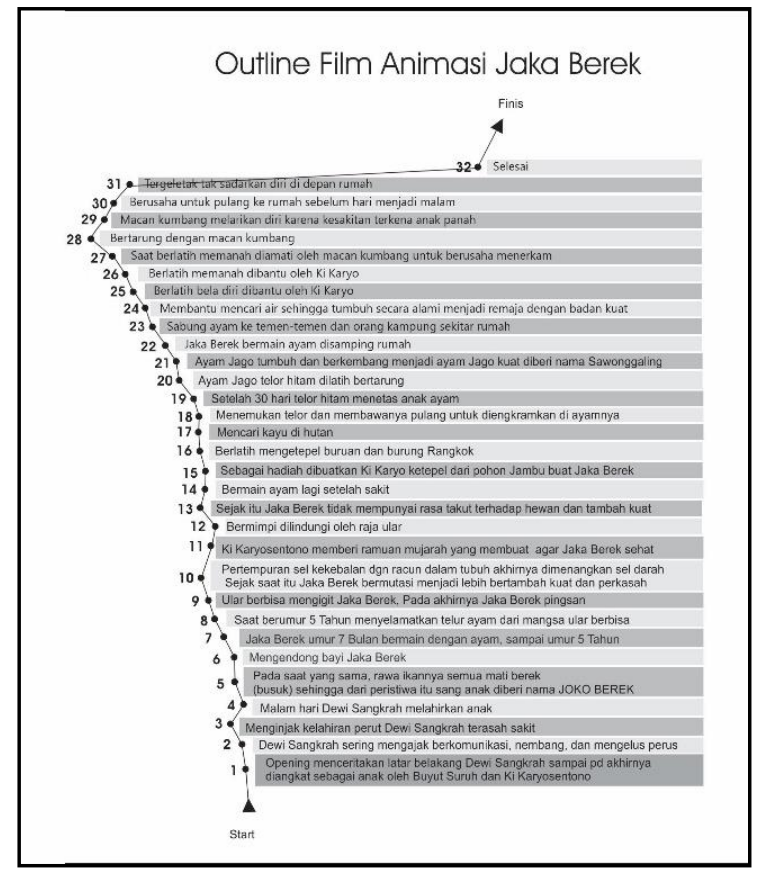

Chart 3. Jaka Berek's story outline (Design: Sutikno, 2020)

\section{2). Script}

After the story has been made in a three-act plot structure, the next step is to create a script. The manuscripts are arranged with the concept of a monologue telling like a puppeteer performing his performance. The language used is the Javanese dialect of Suroboyo typical or it can be said that Javanese Ngoko. Some scenes are made with long shot visuals and some are close up to strengthen the character's character.

\subsubsection{Production}

The making of Jaka Berek's animated films of comic motion has 31 scene scenes which are divided into two sublime character designs 1) Scene 1 - 21 Jaka 


\section{Artistic}

Berek was born to the age of 9 and 2) Scene 21 - 31 Jako Berek is growing up. This lay out division serves to separate the 2 sides of the character's maturity, whose ultimate goal is to strengthen the character's emotions and physicality. In addition, there are separate location settings. Scenes in scenes 1 - 21 use a lot of home settings. The visual color tends to be white to gray showing simplicity and a warm family atmosphere.

Scene 22 - 31 uses a lot of settings in natural environments, one of which is forest. The use of color tends to black because it shows the lush atmosphere of the forest and shows the emotions of the characters getting older. In addition, to strengthen the emotions of the characters in the final scenes.

\section{1). Digital Painting}

This animation production uses Shape Dynamics. The brush strokes are adjusted using shape dynamics to make them appear natural. Long and free imaginative lines form the field of dynamic objects. The combination of stroke pressure and brush options creates a realist painting style.

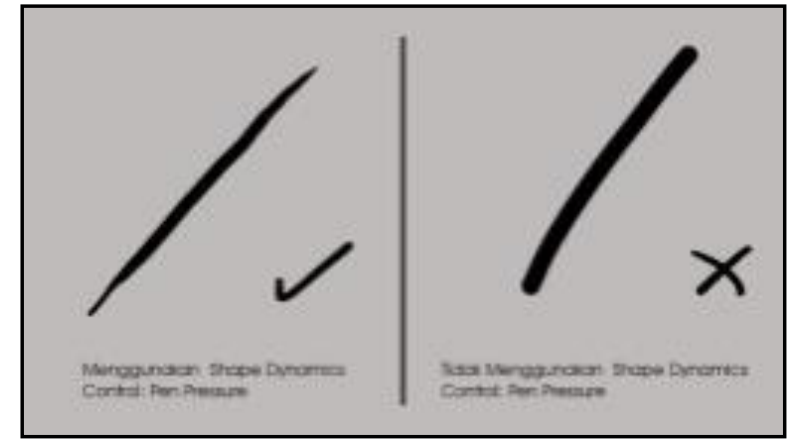

Figure 15. Brush technique type of shape dynamics (Design: Sutikno, 2020)

\section{2). Dubbing}

The dialogue dubbing process is carried out before the animation starts, because it is to determine the long duration of the narration time. In addition, the dubbing results are used as a benchmark for animation movement. Dubbing focuses on 3 characters, including: 
a) The puppeteer as narrator and director of the story uses clear and straightforward Javanese dialect of Suroboyoan.

b) Jaka Berek as a 10 year old child character. Dubbing uses children's voice actors but tends to have deep voice characters which interpret strong and independent children.

c) Dewi Sangkrah as a 30 year old female character who has a soft voice character. However, because Jaka Berek's animated film adapts the Ludruk theater format, the voices that fill are male voices but with female characters and dialects.

\section{3). Animated Motion}

The layer that has been created is then animated by paying attention to animation rules. Animation is displaying images continuously with constant time. In 1 second, Jaka Berek's animated film takes 29 frames per second.

Jaka Berek's animated film without using special computer effects, because it is intended to strengthen the uniqueness of the comics in the film. The author tries to display the effect manually, namely images.

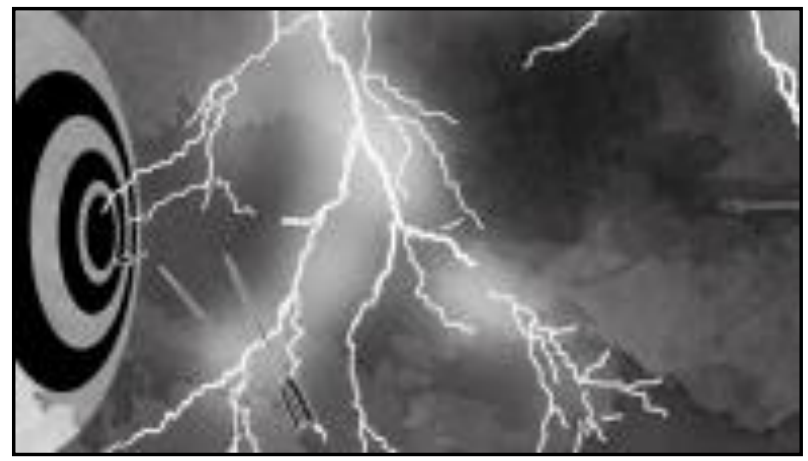

Figure 16. The effect of the arrow on the target (Design: Sutikno, 2020)

The author uses the principle of timing and spacing in certain movements so that the object looks illusory. This movement is seen in scene 30 where Jaka Berek tries to walk towards the house even though it is with difficulty and is limping because his leg is sprained and covered with injuries. 


\section{Artistic}

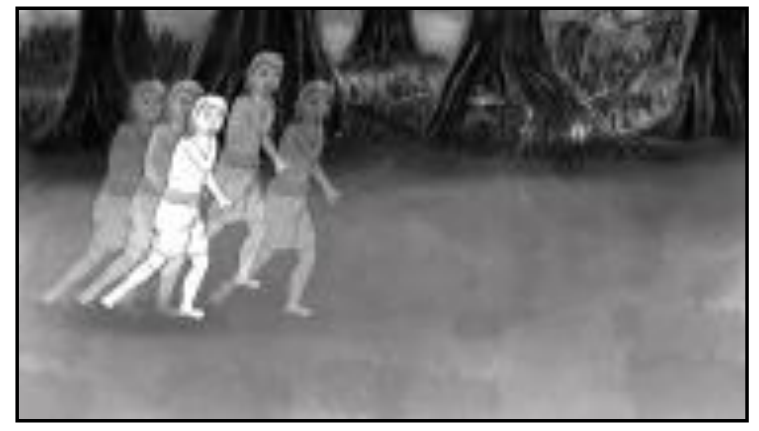

Figure 17. Use of timing and spacing in the scene (Design: Sutikno, 2020)

The writer applies comic principles in making comic panels (McCloud, 1993), among others: from time to time, action to action, subject to subject, and scene to scene.

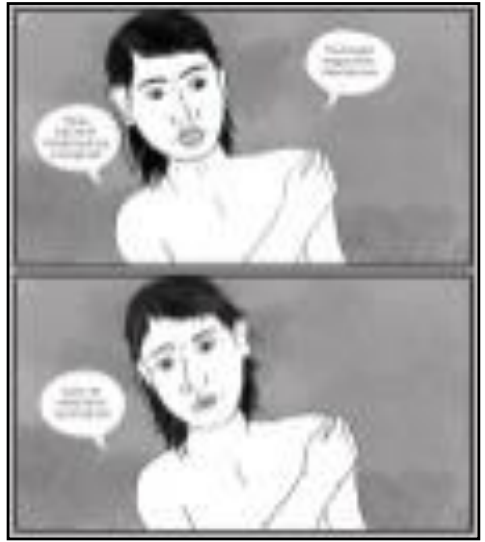

Time to time, scene 30

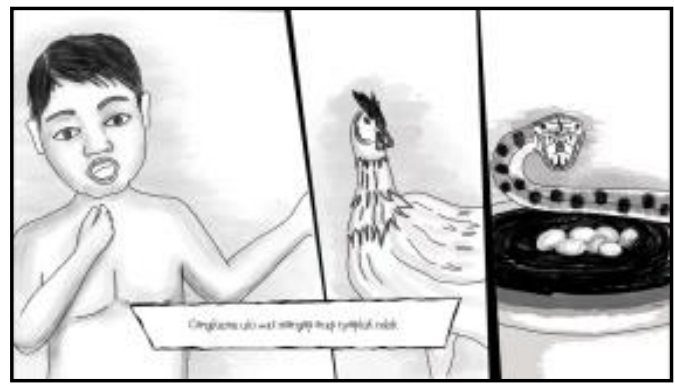

Subject to subject, scene 16

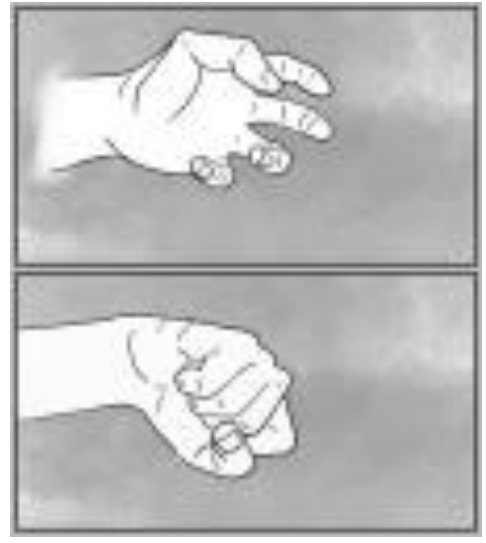

Action to action, scene 29

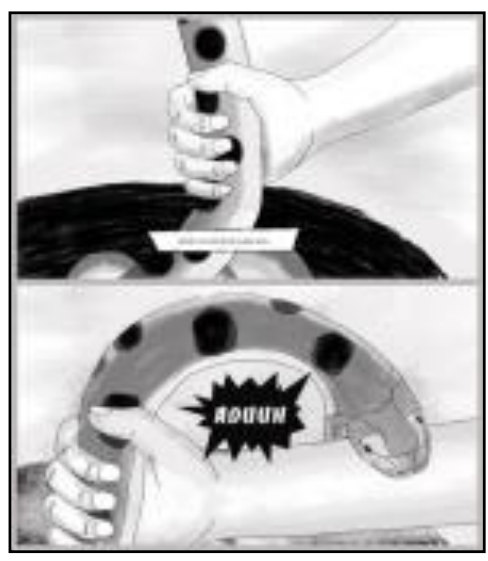

Scene to scene, scene 16

Figure 18. Implementation of comic principles (Source: Jaka Berek, 2019) 
After animating the images in scenes 1 - 31, all files are placed in one special animation result folder, so that it will be easier to manage in the next stage.

\subsubsection{Post-production}

The post-production stage in making Jaka Berek's animated comic film is editing. This stage is very important because if the merging of scenes is not in accordance with the concept, then the desired final result will not be achieved.

The merging of animated scenes into a whole film is done at this stage. The total number of scenes is 31 scenes which are then combined and edited according to the concept at the pre-production stage.

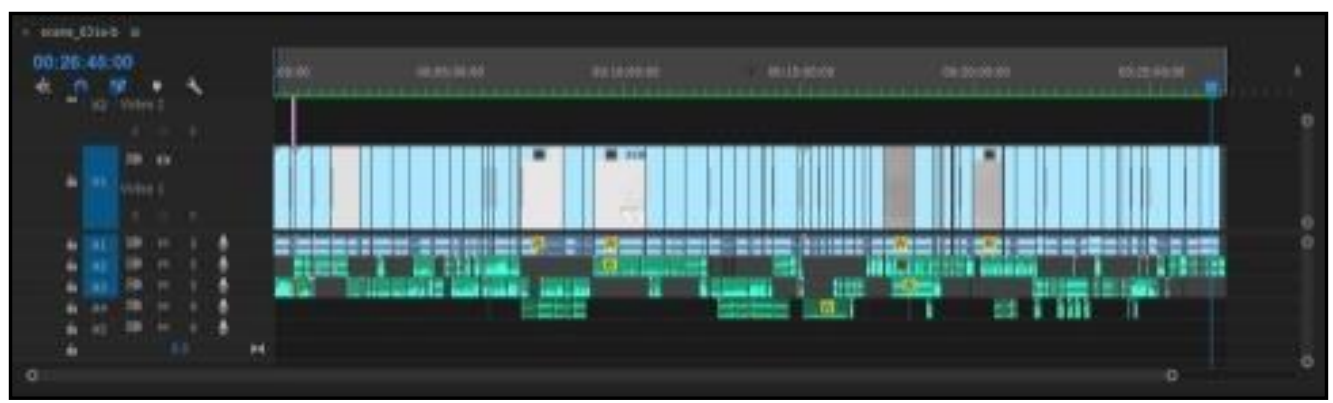

Figure 19. Combining several film scenes into one unit (Editor: Sutikno, 2019)

Moving the scene to the scene to make it look natural, the writer uses the standard dissolve effect. Transitions are not only for animation but also for audio, the transition used is Constant Gain. Audio is downloaded from several free online sites, but has been selected with due regard to unique and ethnic sound characters. Traditional musical sound characters can be played on modern technology tools such as keyboards, synthesizers and midi. Sound Effect uses sounds that represent the existence of the period at that time, for example the sound of water, lightning, chickens, goats, birds, lions, and the atmosphere of the forest.

\section{Conclusion}

From the making of this Jaka Berek animated comic film, it can be concluded that: 


\section{Artistic}

a). To bring back the legends that have been unheard of for a long time, several alternative media that are easily understood by the current generation are needed.

b). Due to the large number of animated film stories today, making animated films with legendary stories needs to be adjusted to the present era so that teenagers are interested in watching them.

c). In making an animated film based on a legend, the creator must conduct research both on the artifacts and ancient manuscripts in order to give a spirit to the work to be produced.

\section{References}

Dakung, S. (1981). Arsitektur Tradisional Daerah Istimewa Yogyakarta. Jakarta: Departemen Pendidikan danKebudayaan.

Eisner, W. M. (2005). Interview Conducted by Charles Brownstein. Milwaukie Oregon: Dark Horse Books.

Field, S. (1984). Screenplay: The Foundations of Screenwriting. New York: Bantam Dell.

Flew, T. (2008). New Media: An Introduction. Melbourne. Melbourne: Oxford University Press.

Guntur, \& Sugihartono, R. A. (2015). Metodologi Penelitian Artistik. Surakarta: ISI Press \& P3AI ISI Surakarta.

Khrisna, M. (2002). Dasar-Dasar Animasi. Jakarta: Elex Media Komputindo.

McCloud, S. (1993). Understanding Comics. New York: HaperCollins Publishers. Inc.

McCloud, S. (2000). Reinventing Comics: How Imagination and Technology are Revolutionizing. New York: HarperCollins Books.

Shamsuddin. (2014). Animation, Concept Art, Dynamic Drawing, Perpective. Journal of Modern Science and Tecnology, 2.

Soedjojono, S. (2000). Seni Lukis, Kesenian, dan Seniman. Yogyakarta: Yayasan Aksara Indonesia.

Soekanto, S. (1990). Sosiologi Suatu Pengantar. Jakarta: Rajawali.

Sugihartono, R. A., Dharsono, \& Guntur. (2020). Therianthropic Conception of Garuda Statue and Relief. International Journal of Advanced Science and Technology, 29(12s), 1460-1470.

Suwasono, A. A. (2017). Konsep Art dalam Desain Animasi. Jurnal Dekave, 10(1). 
Tillman, B. (2011). Creative Character Design. United Kingdom: Elsevier Inc.

Van Dijk, K. (2005). Sarung, Jubah dan Celana: Penampilan sebagai Sarana Pembedaan dan Diskriminasi. Yogyakarta: LKIS.

Zuliati. (2014). Ikonografi Karya Sudjojono "Di Depan Kelamboe Terboeka." Journal of Urban Society's ARTS, 6. 